\title{
Psychosomatic Pain? The Meanings of Musculoskeletal Affliction in Finnish Medicine,
}

\section{ca. 1950-2000}

\author{
Eve-Rüina Hyrkäs \\ Doctoral researcher; History of Sciences and Ideas, University of Oulu, \\ Pentti Kaiteran katu 1, 90570 Oulu, Finland \\ eve-riina.hyrkas@oulu.fi
}

\begin{abstract}
In recent decades, pain has received extensive attention from historians. However, the boundary work between organic and psychogenic pain has been less studied. To address the mind-body problem in the history of pain, this article examines how Finnish physicians in the latter half of the twentieth century have applied the psychosomatic framework to three painful conditions: rheumatoid arthritis, chronic backache and fibromyalgia. Through the interrelated case studies, it is argued that the medical discussion on musculoskeletal pain reflected social and economic interests and values that evolved in the course of the twentieth century. The psychogenic illness explanation compelled physicians to step outside the confines of biomedical rationale. Therefore, the descriptions of the 'mind' behind the 'body' render conspicuous for historians the values, moral norms and social expectations that underlie biomedicine.
\end{abstract}

\section{Keywords}

psychosomatics - pain - mind-body problem - Finland - disability - rehabilitation

What do the wife of a smallholder suffering from rheumatoid arthritis, a working-class man with an eroded spine and a middle-aged woman disabled due 
to persistent pain and fatigue have in common ${ }^{1}$ From the medical perspective, these patients can be classified under the umbrella term 'rheumatism', a group of musculoskeletal and connective tissue illnesses in which pain is a prominent symptom. ${ }^{2}$ The most authoritative current definition of pain by the International Association for the Study of Pain (IASP) states that pain is 'an unpleasant sensory and emotional experience associated with actual or potential tissue damage, or described in terms of such damage. ${ }^{3}$ That mental distress cannot be meaningfully separated from bodily suffering yields that the mind-body interaction has been intrinsic to the attempts to understand pain. Against this background, the instances in which the extensive literature on pain converses with the history of psychosomatics are surprisingly rare. ${ }^{4}$ To address this understudied area, this article examines how Finnish physicians in the latter half of the twentieth century have applied the psychosomatic framework to three interrelated painful conditions: rheumatoid arthritis, chronic backache and fibromyalgia. Through these case studies, I argue that the mind-body discussions of pain reflected social and economic interests, values and expectations that evolved in the course of the twentieth century. More precisely, by a close reading of the psychosocial claims and inferences made by physicians in the changing historical context, this article shows how

1 This study has been conducted as a part of the PROFI-3 (Fibrosis Diseasome) research project and was funded by the Academy of Finland and the University of Oulu.

2 The World Health Organization widened the definition of rheumatism in 1978 to include all musculoskeletal diseases. Finnish rheumatologists soon adopted the broader definition, which included complaints such as lower back pain and fibromyalgia; see Aleksi Ahtola and Veijo Åberg, Pois Reumapeikon Kynsistä: Suomen Reumaliitto 1947-2007 (Helsinki, 2007), 33-36; Veikko Laine, "Reumakäsitettä laajennettava," Reuma, 26 (1978), 1; and Timo Siiskonen, "Selkärankareuma ja kihti," Reuma, 26 (1978), 4-5.

3 See Joanna Bourke, The Story of Pain: From Prayer to Painkillers (Oxford, 2014), 10-12. Defining pain still poses problems to pain researchers, making the IASP definition from the late 1970s a makeshift solution. The continued debate shows in that in 2020, IASP released a revised definition, according to which pain is "an unpleasant sensory and emotional experience associated with, or resembling that associated with, actual or potential tissue damage"; see Srinivasa N. Raja et al., "The Revised International Association for the Study of Pain Definition of Pain: Concepts, Challenges, and Compromises," Pain, 161 (2020), 1976-1982.

4 Recent interest in the history of emotions has fuelled research on the history of pain. The emotional and cultural aspects of pain are discussed, for instance, in the volume edited by Rob Boddice, Pain and Emotion in Modern History (Basingstoke, 2014). Many of its chapters mention psychosomatic theories in passing and some discuss them further, but none are devoted to the mind-body problem. For other works that underline the emotional component of pain and its cultural roots, see, e.g., Javier Moscoso, Pain: A Cultural History (Basingstoke, 2012); David Morris, The Culture of Pain (Berkeley, CA, 1993); Bourke, The Story of Pain; Keith Wailoo, Pain: A Political History (Baltimore, MD, 2014). 
overt and covert non-medical factors played a significant role in the discussions of musculoskeletal pain.

Following the late historian Roy Porter, pursuit of the tendency to differentiate between physical and mental pain leads to a consideration of the problem of psychosomatic disorders. In hysterical pain conditions, the lack of organic lesions gave rise to psychogenic hypotheses; other syndromes, such as chronic fatigue syndrome, still defy unequivocal categorisation and divide medical opinion. ${ }^{5}$ It should be noted that the histories of pain and psychosomatics are connected not only by so-called lesionless pain; ${ }^{6}$ structural injuries have been elementary to conceptions of pain, and the psychosomatic framework has similarly been applied to a range of organic pathologies. ${ }^{7}$ That the domains of psychosomatics and pain overlap (the musculoskeletal diagnoses discussed here are a case in point) does not render the psychological perspective the dominant way of understanding pain. However, as Porter argues, the psychological theories "draw us out to the wider contexts of philosophy, emotion, language, and personal significance, which give meaning to the study of pain". ${ }^{8}$ In agreement with this agenda, this article explores the meanings experts gave to musculoskeletal affliction in the light of the mind-body problem. ${ }^{9}$ The

5 Roy Porter, "Pain and Suffering," in Companion Encyclopedia of the History of Medicine, eds. W. F. Bynum and Roy Porter (London, 1993), 1574-1591, 1575.

6 Psychosomatics is sometimes associated solely with lesionless symptoms, including lesionless pain; see Edward Shorter, From Paralysis to Fatigue: A History of Psychosomatic Illness in the Modern Era (New York, 1992). The approach has, however, been criticised for being "hopelessly anachronistic", as it takes the twentieth-century psychoanalytic assumptions as its starting point; see Andrew Hodgkiss, From Lesion to Metaphor: Chronic Pain in British, French and German Medical Writings, 1800-1914 (Amsterdam, 2000), 9-10.

7 These range from the epitomic stress disease peptic ulcer to gross organic pathology such as malignant tumours or accidental injuries; see respectively Gerald N. Grob, "The Rise of Peptic Ulcer 1900-1950," Perspectives in Biology and Medicine, 46 (2003), 550-566, 56o-563; Patricia Jasen, "Malignant Histories: Psychosomatic Medicine and the Female Cancer Patient in the Postwar Era," Canadian Bulletin of Medical History, 20 (2003), 265-297; and John Burnham, Accident Prone: A History of Technology, Psychology, and Misfits of the Machine Age (Chicago, IL, 2010), 135-138.

8 Porter, "Pain and Suffering," 1584.

9 On ways to address the mind-body problem in medicine, see Anne Harrington, The Cure Within: A History of Mind-Body Medicine (New York, 2009), 15-30; Alexa Geisthövel and Bettina Hitzer, "Psychosomatik - eine Gebrauchsanweisung für dieses Buch," in Auf der Suche nach einer anderen Medizin: Psychosomatik im 20. Jahrhundert, eds. eaedem (Berlin, 2019), 1019; Monica Greco, Illness as a Work of Thought: A Foucauldian Perspective on Psychosomatics (London, 1998). In addition, some feminist studies have pointed out the theoretical relevance of the mind-body dichotomy; see, e.g., Ludmilla Jordanova, Sexual visions: Images of Gender in Science and Medicine between the Eighteenth and Twentieth Centuries (New York, 1989), 19-27. 
study uses the term mind-body boundary work ${ }^{10}$ to refer to a process in which the relevance of psychological and physical determinants in musculoskeletal pain was negotiated, and asks how the symptom has been recognised, problematised and theorised in psychosomatic terms.

Since the Second World War, the treatment of chronic pain has been a target of multidisciplinary efforts, and psychosomatic theories of pain should be situated within these broader endeavours. ${ }^{11}$ It is noteworthy that the bodily sites of pain influenced who participated in the relevant debates, creating variations in the kinds of discussions that were taking place on the subject of pain. In Finland, rheumatologists, orthopaedists, occupational physicians and physiatrists, not to mention psychologists, psychiatrists and neurologists, articulated the treatment problems of musculoskeletal pain and its psychosocial determinants. Patients sometimes entered medical arenas and participated in the mind-body boundary work, as documented in the opinion columns of Reuma ('Rheumatism'), the journal of Finnish Rheumatism Association (FRA). Since the sources mostly portray the perspective of medical experts, this article will discuss these articulations of subjectivity and their relationship to the objectifying tendencies in medicine.

As Alexa Geisthövel and Bettina Hitzer point out, studying psychosomatics allows historians to present "the involved agents and social and scientific lines of conflict concisely". ${ }^{12}$ In accordance with this statement, the cultural and social determinants of psychosomatic pathologies (broadly conceived) have attracted much attention. ${ }^{13}$ The sources used for the present work - medical

10 The use of the term 'boundary work' in this article should be understood separately from the scientific boundary work that serves to outline a particular field of competence or discipline. However, it shares with the latter an interest in instances where tacit assumptions become explicit; see Thomas F. Gieryn, Cultural Boundaries of Science: Credibility on the Line (Chicago, IL, 1999), 1-35.

11 For instance, the staff of the pain clinic established by the American pioneer of pain medicine John Bonica (1917-1994) in the early 1970s already consisted of over twenty specialists. A driving force behind the approach was the gate-control theory of pain, introduced in 1965, which connected pain to psychology and behavioural theories; see Isabelle Baszanger, Inventing Pain Medicine (New Brunswick, 1998), 54-62, 69-70. On pain medicine in Finland, see Tapani Tammisto, Ether-Rausch: Eetteristä erikoisalaksi - Anestesian, teho-, ensi- ja kivunhoidon kehitys kotimaisen kirjallisuuden valossa vuodesta 1847 alkaen (Helsinki, 2012).

12 Geisthövel and Hitzer, "Psychosomatik," 14.

13 See, e.g., Anne Harrington, "Mother Love and Mental Illness: An Emotional History," Osiris, 31 (2016), 94-115; Mark Jackson, The Age of Stress: Science and the Search for Stability (Oxford, 2013); Karl Figlio, "How Does Illness Mediate Social Relations? Workmen's Compensation and Medico-Legal Practices 189o-1940," in The Problem of Medical Knowledge: Examining the Social Construction of Medicine, eds. P. Wright and A. Treacher (Edinburgh, 1982), 174-224; Geisthövel and Hitzer, Auf der Suche nach einer anderen Medizin; Shorter, From Paralysis to Fatigue. 
research and discussions on musculoskeletal conditions and their rehabilitation - trail the claims and sets of practices that merged medicine with social policy and welfare-state development. This article analyses how the social context influenced the discussions of musculoskeletal pain, showing how the historical scrutiny of psychosomatics intersects with medicine, society and culture to extend and shed further light on the history of pain.

\section{The Sensitive Rheumatic in the Post-War Decades}

Following the international example, rheumatism became a topical issue in Finland during the 1930s. ${ }^{14}$ Then, the Finnish physician Lauri Taipale painted a threatening image of how the "pale and crippled" Finnish arthritics, like their Swedish and Danish counterparts, would soon "flood" the hospitals. ${ }^{15}$ In 1936, an internationally acclaimed epidemiological survey on the prevalence of rheumatoid arthritis in Finland demonstrated the social significance of the disease. Out of the 1,177 cases of chronic joint disease studied, nearly 70 per cent were partially or fully unable to work..$^{16}$ That over $5^{\circ}$ per cent of sufferers had received no medical care whatsoever began to seem like critical neglect. ${ }^{17}$ This section outlines the psychological theories of rheumatoid arthritis and rheumatic pain from the 1950s to the 1970s and links their development to contemporary rehabilitation practices. The attitudes that patients adopted with respect to their symptoms were explained through personal characteristics, psychopathology and problematic emotions. Sometimes the symptoms themselves were explained in these terms. Even in cases where an anatomic lesion was found, this did little to diminish the moralistic content of medical discussions on rheumatoid arthritis, reflecting the fluid margin between organic and psychogenic pain.

Chronic degenerative diseases became a growing problem in Finland following the Second World War. The development called for an intensive

14 Veikko Laine, Reumahoidon kehityksestä Suomessa: katsaus aikaan ennen 17.7.1951 (Helsinki, 1985), 14-18.

15 Lauri Taipale, "Nykyajan reumakysymyksestä," Duodecim, 46 (1930), 485-49o, 489-49o.

16 Östen Holsti and Viljo Rantasalo, "On the Occurrence of Arthritis in Finland," Acta Medica Scandinavica, 88 (1936), 180-195, 183, 190, 192. By the 196os, a common evaluation was that there were 100,00o rheumatics in Finland (a country with a total of four and a half million inhabitants), of whom 15,000 were receiving disability pensions; see Mauno Nevalainen, "Reuma sosiaalisena ja sosiaalisena kysymyksenä," Reuma, 8 (1960), 30-34, 30.

17 Osmo Paloheimo, "Kroonisten niveltautien esiintymisestä Suomessa ikäluokissa 18-54 v." Duodecim, 57 (1941), 247-273, 271. 
rehabilitation practice, which was applied to combat the mobility restrictions and pain in rheumatoid arthritis. As historical research regarding Swedish rehabilitation policies suggests, the rehabilitation of rheumatism and neuroses shared a number of features. Both were illnesses that incapacitated patients without fully destroying their health; patients were admitted to treatment facilities based on an evaluation of their probable recovery; and, as is argued here, rehabilitation for rheumatism attempted to strengthen the morale and the will of the patients. ${ }^{18}$ In pursuit of the goal of an economically effective workforce, disability was seen not merely as a function of the severity of physiological impairment. ${ }^{19}$ Echoing the tenets of Finland's agrarian past, the appreciation of hard work and physical strength transferred to the post-war wage-earning society. ${ }^{20}$ The medical discussion of pain was not untouched by these expectations of sturdiness. By suggesting that there was some shortcoming in the personality of a patient who did not recuperate at the expected rate, it created a moral pressure for a speedy recovery. ${ }^{21}$

In Finland's post-war disability policies, invalids were commonly associated with images of dependency and degeneration. ${ }^{22}$ These associations were also applied to patients with joint disease even though they lacked some of the determinants of other invalid groups - they were neither wounded heroes nor congenitally impaired. In 1955, an editorial in Reuma claimed that rheumatics were an apathetic group that did not stand up for themselves; both reader responses and general rehabilitation practices seemed to confirm that this was the prevailing attitude. ${ }^{23}$ The goal of social and medical rehabilitation was to counteract the alleged passivity of rheumatics so that the patients would take control over their lives. ${ }^{24}$ The first comprehensive Finnish textbook on

18 Petteri Pietikäinen, "Strengthening the Will: Public Clinics for the Nervously Ill in Sweden in the First Half of the Twentieth Century," Social History of Medicine, 22 (2008), 115-132, 120-123.

19 Veikko Niemi, "Kuntouttamista vai kuntoutumista," Reuma, 9 (1961), 21-24, 21-22.

20 Jussi Turtiainen and Ari Väänänen "Men of Steel? The Masculinity of Metal Industry Workers in Finland after World War II," Journal of Social History, 46 (2012), 449-472, 453-454.

21 Similar moralistic content in discussions of rheumatoid arthritis was observed in the US; see Wailoo, Pain, $55^{-56}$.

22 Heli Leppälä, "Welfare of Workfare?: The Principle of Activation in the Finnish Post-War Disability Policy, Early 1940s to Late 198os," Journal of Social History, 49 (2016), 959-981, 964.

23 Editorial, "Ovatko reumasairaat apaattisia?" Reuma, 3 (1955), 3-5; W.W. (pen name), "Reuma ja apatia," Reuma, 3 (1955), 17.

24 R. K. Luukkonen, "Reumapotilaiden sosiaalinen huolto Reumasäätiön sairaalassa," Reuma, 1 (1953), 20-22; idem, "Näköaloja kroonisten sairaitten ja lähinnä nivelreumatismia sairastavien potilaitten sosiaalisesta huollosta," Reuma, 2 (1954), 14-18; Risto Vilkka, "Omatoimisuuden periaate sosiaalihuollossa," Reuma, 7 (1959), 14-19. 
rehabilitation, published in 1962, saw rehabilitees as "psychophysical entities", whose "varying attitude and mood" (original emphasis) set the pace for recovery. ${ }^{25}$ These remarks implied that pain and disability could be overcome by developing the patient's mental faculties. The insistence on keeping patients physically active was interwoven with everyday treatment practices, for instance by expecting that rheumatics made their own beds during hospital treatment.

Failed rehabilitation fell in with the characterisation of patients as overly pain-sensitive and even work-shy. In the US, the rehabilitation researcher Edward Lowman and his colleagues identified dependent or hypochondriac tendencies as an essential feature of the "unsuccessful rehabilitee". ${ }^{26}$ These views also resonated in Finland. In 1955, Veikko Laine (1911-2001), ${ }^{27}$ the first to be appointed head physician of the Rheumatism Foundation Hospital $(\mathrm{RFH})$ in Heinola, ${ }^{28}$ summarised Lowman's rehabilitation experiments in New York. ${ }^{29}$ In 1959, Laine, with the nurse Aili Leminen, published his own study on the psychological aspects of a typical rheumatic. Drawing from psychoanalytic assumptions, Laine suggested that it was the patient's personality, rather than their medical status, that was behind a slow recovery. In addition to bringing out the near-paradigmatic bifurcation between passivity and activity, Laine asserted that rheumatic patients' readiness to feel pain stemmed from their bodily and psychological sensitivity, as rheumatics were inclined to "watch for all kinds of symptoms in any part of the body, now here, now there". The authors drew a parallel between this kind of sensitivity and more severe neurotic disturbance that was "not uncommon" in rheumatics. ${ }^{30}$ Hence, the

25 Antti Tamminen, "Kuntouttamisen ja kuntoutumisen psykologiaa," in Kuntouttaminen, eds. Leo Noro et al. (Helsinki, 1962), 20.

26 Edward W. Lowman et al., "Psycho-Social Factors in Rehabilitation of the Chronic Rheumatoid Arthritic," Annals of Rheumatic Diseases, 16 (1954), 312-316, 316.

27 Throughout his life, Veikko Laine was a central figure in Finnish rheumatology. In his clinical and scientific work, he advocated a view that the psyche and social factors influenced the progression of joint disease. Laine's original specialisation in mental and nervous diseases may partly explain his holistic outlook towards rheumatic diseases. Laine's views on different forms of rheumatism were disseminated through his work in the Rheumatism Foundation Hospital in Heinola, the training centre for most Finnish rheumatologists.

28 Heinola remained as the main site for the treatment and rehabilitation of rheumatic diseases until it was shut down in 2010; see Markku Kauppi et al., "Beware of the Biologicals - Hospitals May Die: The Rheumatism Foundation Hospital, Heinola, Finland (1951-2010),” Clinical Rheumatology, 31 (2012), 1151-1154, 1153 .

29 Veikko Laine, "Reumapotilaiden kuntouttamisesta, E. Lowman, P. Lee, H. Rusk, New York," Reuma, 3 (1955), 7-8.

30 Aili Leminen and Veikko Laine, "Psychological Aspects of the Rehabilitation of the Rheumatoid Arthritis Patient," International Nursing Review, 8 (1959), 33-35. 
psychological component of rehabilitation concerned not only the patient's motivation to return to the labour market, but also their predisposition to feel and endure pain, the dismal attendant to joint disease. The ability to withstand physical suffering has a long history as a measure of personal qualities, and these Finnish studies evaluating the reactions to rheumatic pain were no exception. ${ }^{31}$

In his 1964 medical textbook Reumataudit ('Rheumatic diseases'), Laine tackled the issue of why some patients seemed to dwell on the pain experience. He noted that pain was closely related to anxiety, as they both had an unpleasant emotional content. Mood and childhood experiences were believed to mould reactions to pain. More importantly, long-standing pain appeared to have a "demoralizing effect" - afraid of its worsening, patients' tendency to avoid working altogether could set them on to a trajectory of pain disability. With this threat in mind, Laine provided a checklist for recognizing, and evaluating the levels of, psychogenic pain that did not align with organic pathways. The pain was "probably functional or psychogenic" if its location or portrayal were obscure, if the pain was aggravated by bad mood or draught of air, and if the common pain medications were ineffective. ${ }^{32}$ Laine's list resembled in many respects the description that the American internist-psychiatrist George Engel provided in his influential 1959 article, "Psychogenic' Pain and the Pain-Prone Patient". Like Laine, Engel also emphasised that although pain always had a psychological component, there was a group of patients who were particularly susceptible to it. ${ }^{33}$

While Finnish physicians discussed non-organic pain in cases of fibrositis or muscular rheumatism, these conditions were usually deemed only a temporary nuisance that did not permanently destroy a patient's ability to work. ${ }^{34}$ This somewhat indifferent approach was sustained alongside strict compensation

31 Bourke, The Story of Pain, 192-193, 222-229.

32 Veikko Laine, Reumataudit (Helsinki, 1964), 12-13.

33 George L. Engel, "Psychogenic Pain' and the Pain-Prone Patient," American Journal of Medicine, 14 (1959), 899-918, 903-904; Veikko Laine, "Nivelreuma," Reuma, 7 (1959), 6-12, $8-9$.

34 Rauno Heikinheimo “Överkroppens bindvävssmärtor ('muskelreumatism')," Reuma, 7 (1959), 17-19, 18. Muscular rheumatism was a condition characterised by pain in connective tissue and nodules in the affected muscles. Its alleged causes ranged from physical overexertion to nervousness; see, e.g., Saima Tawast-Rancken, "Rasituksen aiheuttamista lihaskivuista," Reuma, 1 (1953), 11-13; Lars Tötterman, "Lihasreumasta," Reuma, 4 (1956), 5-8. On the history of fibrositis, see Michael D. Reynolds, "The Development of the Concept of Fibrositis," Journal of the History of Medicine and Allied Sciences, 38 (1983), 5-35. 
regulations. ${ }^{35}$ Yet, also in cases of actual rheumatic disease, the gap between subjective pain experience and medical findings could, in Laine's words, lead to injustice. Based on one medical certificate, social insurance and taxation authorities might not deem a person disabled, whereas another doctor could provide a wholly contrary opinion. ${ }^{36}$

From the 1960s onwards, Finnish authors put a particular emphasis on aggression dynamism in rheumatoid arthritis. The idea was derived from the psychosomatic personality theory of the disease which emerged in the mid-twentieth century in Europe and the US. ${ }^{37}$ The Finnish psychiatrist Ranan Rimón (b. 1938), whose views on the psychodynamism of rheumatoid arthritis conformed with Laine's clinical observations, wrote in 1969 how social and moral norms inhibited the free expression of anger. Hence, aggression could be directed to the patient's joints in the service of social adaptation. Rimón persisted with this idea despite the fact that people with arthritis were rarely overtly aggressive. ${ }^{38}$ Similarly, Laine noted in both Reuma and the health-care magazine Terveydenhoitolehti that arthritics were generally reserved and kind people, who repressed their anger. ${ }^{39}$ The epistemic problems of interpreting both peaceable behaviour and fits of anger as signs of aggression are evident. As Carol Zisowitz Stearns and Peter Stearns write, the Freudian conception of anger, which conflates it with aggression, does not give full recognition to the fact that anger is the underlying emotion, whereas aggression is only one of its overt expressions. ${ }^{40}$

35 Finland was a latecomer in establishing social insurance policies, and unemployment benefits and pension schemes were applied in earnest only during the 1950s. Sickness insurance, which made healthcare services available to the wider public, was not passed until 1963. The great expansion of social security only took place after the early 1970s; see Pauli Kettunen, "The Nordic Welfare State in Finland," Scandinavian Journal of History, 26 (2001), 225-247, 235-238.

36 Laine, "Nivelreuma," 9-12.

37 Central works included: Gotthard Booth, "Personality and Chronic Arthritis," The Journal of Nervous and Mental Disease, 85 (1937), 639-662; James L. Halliday, "The Concept of Psychosomatic Rheumatism," Annals of Internal Medicine, 15 (1941), 666-677; and Franz Alexander, Psychosomatic Medicine (New York, 1950). On Halliday, see also Rhodri Hayward, "Enduring Emotions: James L. Halliday and the Invention of the Psychosocial," Isis, 100 (2009), 827-838; Andrew Hull, “Glasgow's 'sick society?': James Halliday, psychosocial medicine and medical holism in Britain c. 1920-48," History of the Human Sciences, 25 (2012), 73-9o.

38 Ranan Rimón, A Psychosomatic Approach to Rheumatoid Arthritis (Turku, 1969), 80-81, 96-97.

39 Outi Pennanen, "Missä syy kun reuma puhkeaa," Terveydenhoitolehti, 77 (1972), 22-25; eadem, "Missä syy kun reuma puhkeaa," Reuma, 20 (1972), 3, 15.

40 Carol Zisowitz Stearns and Peter Stearns, Anger: The Struggle for Emotional Control in America's History (Chicago, IL, 1986), 8. 
Unlike overt aggression, depression was commonly found in people with arthritis - up to 8 o per cent of patients at the RFH were, at some point in the course of their disease, also thought to be suffering from depression, which was believed to make rheumatic pain worse. ${ }^{41}$ Given that women are two to three times more likely to develop rheumatoid arthritis than men, it is intriguing to what extent the hypotheses about rheumatoid personality were related to the gender of patients. As to women and mental illness, the literature suggests that aggression is often viewed as an active, male trait, whereas the more passive and withdrawn ways of expressing distress, such as depression, are more readily associated with women. ${ }^{42}$ All Rimón's research subjects were female, and he made use of the well-known theory of the Hungarian-American psychoanalyst Franz Alexander (also based on female patients) in which the rejection of the feminine role was presumed to invoke "a masculine protest reaction", expressed through the "benevolent tyranny" of a "battleaxe". If the patient could not express her hostility in this way, it was believed to be redirected to the joints. ${ }^{43}$ In Finland and elsewhere, the psychosomatic theories stated that arthritics not only over-reacted to their illness, but were also self-sacrificing, rigid, moralistic, conforming, overly self-conscious, shy, inhibited and perfectionistic. ${ }^{44}$ These formulations reflected the predicament in which arthritics lived, as many sufferers were poor, working mothers with multiple children and no outside help. ${ }^{45}$ I contend that because it was predominantly women who were afflicted with rheumatoid arthritis, the attributes given to the female gender (sensitivity, timidity and passiveness) in part guided researchers when they attempted to construct a pathological personality profile of people with arthritis. The psychosomatic theories were rightly criticised in Finland in the 198 os for interpreting special social circumstances as personality constellations. The situation of a mother with many children who received no outside

41 Heikki Isomäki and Veikko Laine, Reuma (Helsinki, 1976), 55, 58-59, 97.

42 See Phyllis Chesler, Women and Madness (New York, 1973), 38-46. For a critical evaluation, see Joan Busfield, "Mental Illness as Social Product or Social Construct: A Contradiction in Feminists' Arguments?" Sociology of Health \& Illness, 10 (1988), 521-542.

43 Alexander, Psychosomatic Medicine, 201-209.

44 For a contemporary review, see, e.g., Rudolf Moos, "Personality Factors Associated with Rheumatoid Arthritis: A Review," Journal of Chronic Diseases, 17 (1964), 41-55. In Finland, see Juhani Rekola, Rheumatoid Arthritis and the Family (Helsinki, 1973).

45 Juhani Kirpilä, "Sosiaalisten olosuhteiden merkitys nivelreumassa," Reuma, 6 (1958), 13-14; Veikko Laine, R. K. Luukkonen and L. Tiirikainen, "Havaintoja nivelreumaa sairastavan sosiaalisesta asemasta ja huollon tarpeesta," Reuma, 7 (1959), 24-25; Leena Nirsinen, "Nivelreumaa sairastavan perheenäidin sosiaalinen asema," Reuma, 14 (1966), 3-4. 
help could easily be interpreted - and frequently was interpreted - to reflect the "self-sacrificing" psyche of the patient. ${ }^{46}$

In discussions of rheumatoid arthritis in the 1970s, emotional issues dependence, depression and anger - still figured prominently. However, they were increasingly viewed as natural, even necessary, consequences of falling ill with a debilitating disease. The dissertation of the psychologist Pirkko Kiviniemi (1931-2006), who had long clinical experience at the RFH, placed a strong emphasis on the sick role theory and psychological reactions caused by the disease. ${ }^{47}$ Kiviniemi also paid attention to the psychological and behavioural changes that could follow chronic pain. As she explained in 1974, persistent pain was a psychological burden that evoked emotional reactions and distorted behavioural patterns. Although terms such as "hypochondria", "hysteria", "simulation", "compensation neurosis", and "pain mannerism" had moralistic connotations, Kiviniemi argued that pain always constituted a real threat to the patient. ${ }^{48}$ It appears that the improved treatment techniques and early intervention that had alleviated the most severe debilitating outcomes of rheumatoid arthritis created more room for discussion on the less tangible elements of rheumatic disablement.

The changes in rheumatoid arthritis discussions were related to broader trends in musculoskeletal health. In 1975, a report on rheumatoid arthritis noted that the financial and social significance of the disease was diminishing at the expense of other joint and muscle ailments. Over the course of a near decade (1965-1973), the amount of disability pensions due to musculoskeletal illnesses had more than tripled among people in their late forties and early fifties, and this disease group now accounted for over 26 per cent of all new disability pensions. However, no sudden deterioration of musculoskeletal health seemed to explain its sudden appearance among the most pressing public health issues of the time. Led by Heikki Isomäki, the head physician of $\mathrm{RFH}$, the report authors conjoined the rise of musculoskeletal illnesses with the profound changes that had taken place in Finnish society, namely urbanisation, industrialisation and the improvement of social welfare. Suggesting that musculoskeletal patients were cashing in on the welfare benefits, the

46 Kari Lahtela and Eeva Karttunen, Nivelreumapotilaan persoonallisuus, sairauteen sopeutumistyyli ja mielenterveys sairauden varhaisvaiheessa (Turku, 1985), 6.

47 Pirkko Kiviniemi, "Emotions and Personality in Rheumatoid Arthritis," Scandinavian Journal of Rheumatology, 18 (Supplementum 6, 1977), 7-9.

48 Pirkko Kiviniemi, "Kipu kumppanina," Reuma, 12 (1974), 10. 
arthritis report concluded that attitudes and values had changed, and people were looking forward to an early retirement. ${ }^{49}$

\section{Back-Pain Patients in the 1980s: Shirkers, Deviants, or Simply Ill?}

Growing levels of disability posed a series of problems and reoriented the medical approach to musculoskeletal complaints. According to Deborah Stone, the crisis of disability pension programmes in Western countries had multiple common features: expenditures were growing; the increase peaked near the mid-197os; the value of disability benefits rose; terminations of pensions were in decline; and the disability criteria were changing. Disability benefits were also increasingly allotted to illnesses that were the hardest to validate, such as mental illnesses and back pain..$^{50}$ In Finland, the trend gave rise to fierce socio-medical discussion on the supposed degeneration of spines. By 1983, the Musculoskeletal Strategy Committee in its "back treatment strategy" stated that pain was a health issue emblematic of "modern times". ${ }^{51}$

This section focuses on the psychosocial theories on the causes of back pain that gained ground during the economic upturn of the 1980s, and engaged a great variety of experts. The theories addressed the porous boundary between psychopathology and malingering, as well as the boundary between organic and psychogenic pain.

Much contemporary attention had already been paid to the structural reasons behind back pain. Timo Klaukka, the head of research at the Social Insurance Institution of Finland (Kela), noted in 1983 that automation and the monotonous strains of work had probably increased the amount of musculoskeletal complaints. He continued that the higher number of people seeking disability pensions resulted from the disappearance of jobs from the

49 Heikki Isomäki et al., Nivelreuma sosiaalilääketieteellisenä ongelmana (Tampere, 1975), 40-41.

50 Deborah Stone, The Disabled State (Philadelphia, PA, 1984), 8-10. In Finland, the expansion of welfare programmes continued during the 198 os after a quick recovery from the 1970 s economic depression; see Heikki Niemelä et al., Suomalaisen sosiaaliturvan kehitys ja kansalaisen elinvaiheet (Helsinki, 2007), 5-7. On illness trends, see also Ari Väänänen and Jussi Turtiainen, "Suomalaisen työntekijyyden ja työntekijäideaalien historiaa," in Suomalainen työntekijyys 1945-2013, eds. Ari Väänänen and Jussi Turtiainen (Tampere, 2014), 18-53, 35, 49-51.

$5^{1} \quad$ Strategy Committee on Musculoskeletal Diseases (SCMD), Tuki- ja liikuntaelinsairauksien ehkäisy ja hoito - Selkäohjelma (Helsinki, 1983), 27. In 1982, lower-back symptoms were the cause of 34,161 disability pensions, constituting 14 per cent of all disability pensions; see ibid., $16-17$. 
agricultural sector. Acquiring a new occupation was difficult for middle-aged people with a low starting level of education, to whom taking an early pension would therefore seem a viable option. Furthermore, it seemed that the better provision of healthcare services had been conducive to their wider use. ${ }^{52} \mathrm{~A}$ plea dating back to the 196os for improving the state of the Finnish healthcare system had finally gotten the "men with hardened veins and rheumatic joints" to see their doctors, but with a surprising downside..$^{53}$ Thanks to improved recognition of functional complaints in the medical practice, in the 1980s it was not only those with progressed medical conditions, but also those with more vague, subjective symptoms who were now seeking medical help.

The significance of the health experience showed in Sosiaalilääketieteellinen Aikakauslehti ('The Journal of Social Medicine') in 1982, when a special issue was devoted to exploring recent medical research on subjective (or psychosomatic) symptoms. ${ }^{54}$ It emphasised that it was the experience of health or illness, and not, for instance the objective destruction of articular cartilage, that dictated the use of healthcare services..$^{55}$ The claim stressed the difference between the perspective of physicians and that of patients with regard to pain. For a medical practitioner, the focus of attention was on the most readily identifiable underlying pathology, whereas the suffering patient knew only the extent and rough location of their pain. Contemporaries seemed eager to speak for patient experience, but it is imperative to note that when the experts talked of the patient's view they described what was heard and perceived, not the patient experience itself. ${ }^{56}$

As a case in point, physicians could interpret pain descriptions in a way that created potential for confrontation. The image of the typical person complaining of backache became audaciously unflattering. The rheumatologist and adjunct professor of social medicine Kai Sievers (1930-1994) contended in 1981 that patients with "a career of back pain" were "disabled", "fixated to their pain symptom", had "a great risk of suicide" but "no self-esteem or close relationships", which was why they "bitterly sought a decent income from the

52 Timo Klaukka, Kai Sievers and Jorma Takala, "Tuki- ja liikuntaelinsairauksien esiintyvyys Suomessa 1964-1976," Sosiaalivakuutus, 21 (1983), 110-117, 110, 115-116.

53 For the quote, see Pekka Kuusi, 6o-luvun sosiaalipolitiikka (Helsinki, 1961), 266.

54 Matti Rimpelä, "Koettu on todellista - siis tieteellisesti tutkittavissa," Sosiaalilääketieteellinen Aikakauslehti, 19 (1982), 201-205.

55 Seppo Aro, Marja Jylhä and Olavi Paronen, "Psykosomaattiset oireet ja koettu terveys - Sosiaalilääketieteellinen näkökulma," Sosiaalilääketieteellinen Aikakauslehti, 19 (1982), 206-211.

56 See, e.g., David Armstrong, “The Patient's View," Social Science \& Medicine, 18 (1984), 737-744. 
social insurance system". ${ }^{57}$ Although Sievers made a point that the description did not apply to milder cases, such characterisations were often repeated in the medical discussion. For instance, a year later, in a seminar on the reasons and treatments for pain, the orthopaedist Kalevi Österman stated that low socioeconomic status, a lack of motivation to return to work, sensitivity to somatic and psychosomatic pain and dependence on others made for a poor prognosis after a spinal disc surgery; to his mind, the quality of the prognosis was closely related to the goal of financial compensation. ${ }^{58}$ It appears that the backache debate involved many of the same factors as the discussions of rheumatic pain, but that medical opinion became more critical as the fear of welfare-system exploitation intensified. Suspicion of patients' motives was by no means unique to Finland. In the US, "low-back losers" became the chief culprits blamed for the swelling disability rolls. ${ }^{59}$

An excerpt from the backache debate in Reuma illustrates that the mindbody boundary work took contentious forms. One article written by the physiatrist Erkki Valtonen (1934-2020), the head of the physical rehabilitation centre of Meilahti, stoked particular outrage. In 1981, Valtonen contended that the real reason behind the back-pain epidemic was improved social welfare; if the threshold for disability pension was low, it was "only natural" that people would take advantage of this loophole in the system. Since the spine allegedly held a metaphorical significance as the "supporter of life", Valtonen continued that back illness probably channelled psychological troubles. ${ }^{60}$ This contention, and his failure to mention the organic causes of back complaints (arthrosis, ankylosing spondylitis and spinal disc herniation to name a few), prompted fierce criticism in the opinion columns. Back patients seemed just as outraged by Valtonen's allegation that they were cheats as they were with his suggestion that back pain could have a psychological origin. In one reader's opinion, physicians only invoked the psychological explanation when they wanted to accuse the patient of malingering, but could not find enough evidence to do so. ${ }^{61}$ Another reader felt that she might as well quit her active participation in

57 Kai Sievers, "Nykyajan epidemia," Reuma, 29 (1981), 1-2.

$5^{8}$ Kalevi Österman, "Psyykkiset ja sosiaaliset tekijät välilevytyräpotilaiden kuntoutuksessa," in Kivun syyt ja säätely, eds. Kai Sievers, Veikko Laine and Raimo Raitasalo (Helsinki, 1982), 257-26o, 259-26o; see also Matti Hurme, "Selkäleikkauksen aiheellisuus ja leikkaustulokset," in Kuinka kuntoutua kroonisesta selkäkivusta, ed. Markku T. Hyyppä (Turku, 1986), 3946; Hannu Alaranta, "Kuntoutuminen selkäleikkauksen jälkeen," in Kuinka kuntoutua kroonisesta selkäkivusta, ed. Markku T. Hyyppä (Turku, 1986), 47-55.

59 Wailoo, Pain, 93-97.

6o Erkki Valtonen, "Näkökulmia maamme selkäsairausepidemian hoitamisesta," Reuma, 29 (1981), 1-3.

61 J. Aatos Suominen, "Vastine Valtosen kirjoitukseen," Reuma, 29 (1981), 25. 
Finnish rheumatism work, given that she was nevertheless deemed "socially and psychologically disturbed, work-shy and oversensitive to pain".62

Reservations towards psychologisation were not without grounds. Sometimes, even a severe intervertebral bulge eventually leading to paralysis was for a long time misinterpreted as pain neurosis. ${ }^{63}$ On the other hand, doctors' use of pain as a pretext to grant dignified sick leave in cases where they suspected psychological causes was also indicative of patients' preference for a somatic diagnosis. The Finnish social scientist Ari Väänänen and his colleagues have interviewed an occupational health physician, according to whom psychological syndromes were subsumed into categories of physical health complaints like back pain, neck pain, headache and so forth in the early 1980s. Other interviewees agreed that the practice to stay within the anatomical framework "respected the patient's will" not to disclose their mental health problems and psychological stresses in the medical practice. ${ }^{64}$

Back pain had long been of interest to Finnish physicians, but the sheer numbers of people claiming pain disability made it newly topical. ${ }^{65}$ In the 1980s, psychosomatic theories were increasingly invoked to foster a holistic approach to back pain. In 1985, an article in the largest Finnish medical journal, Duodecim, called for research on psychosocial risk factors of back ailments to unveil "something similar [to what] Type A is to coronary diseases". ${ }^{66}$ Back pain could help a stressed person to escape a difficult life situation, when the "weakest organ gave in under pressure".67 Even theories of a specific "back personality" were briefly summoned. Rehabilitation researcher Kari Lahtela offered the playful summary that in fifty years, back personality theories had progressed from anaclitic (dependent) to alexithymic (literally, no words for feelings). The idea of alexithymia, an inability to put emotions into words, was one of the theoretical apparatuses used to explain a tendency to somaticize,

62 Anneli Perkola, "Dosentti Valtosen kirjoitus Reuma-lehdessä no 3," Reuma, 29 (1981), 25.

63 Annika Lillrank, "Kärsimys, kipu ja moraali: kertomus selkäkipupotilaan ja terveydenhuollon kohtaamisesta," Nikama, 17 (2006), 10-14, 13.

64 Ari Väänänen et al., "From Silence to Diagnosis: The Entry of the Mentally Problematic Employee into Medical Practice," Social Theory \& Health, 17 (2019), 407-426, 413-414.

65 On the history of back pain in Finland, see, e.g., Tammisto, Ether-Rausch, 188-207.

66 Kai Sievers and Timo Klaukka "Mitä tulisi tehdä selkäkipujen torjumiseksi," Duodecim, 101 (1985), 75-82, 76. On the history of Type A, see, e.g., Harrington, The Cure Within, 161-170; Jackson, The Age of Stress, 208-210; and Elianne Riska, "From Type A Man to the Hardy Man: Masculinity and Health," Sociology of Health and Illness, 24 (2003), 347-358.

67 Leo Stjernvall, "Selkäpotilas saatava uskomaan omaan paranemiseensa," Reuma, 32 (1984), 14 . 
that is, to express emotions through bodily complaints. ${ }^{68}$ The Finnish authors noted repeatedly that back pain could signify an underlying "psychosomatic reaction pattern" that fostered this kind of somatic expression of strain. ${ }^{69}$ It is noteworthy that somatisation was viewed in close proximity to malingering and factitious disorders. Following the sociologist Monica Greco's thought, the smallest common denominator of these illness was that they appear false from the biomedical perspective, and the only pathological feature is the patient's insistence on receiving medical help. ${ }^{70}$

Back pain challenged the traditional ways of evaluating disability, and outlining the psychological component of pain was a complex undertaking. ${ }^{71}$ Attempts to find an organic cause to the symptom could backfire, if the patient was prematurely introduced to, for instance, an X-ray showing changes that upon closer inspection were found not to explain the pain symptom. This iatrogenic mechanism could create so-called "X-ray invalids", who held an unwavering belief that the radiograph showed the underlying cause of their suffering. ${ }^{72}$ As the orthopaedist Olli Korkala insisted, psychological evaluation should also precede a lumbar disc surgery in cases of chronic back pain. "Psychological fixation on the pain condition" hindered post-surgical recovery, and made considering continued conservative treatment advisable. ${ }^{73}$

As public concern about subjective ailments intensified, rehabilitation experts were called upon to tackle what appeared to be changing illness

68 Kari Lahtela, "Psyykkiset tekijät selkävaivoissa," in Kuinka kuntoutua kroonisesta selkäkivusta, ed. Markku T. Hyyppä (Turku, 1986), 11-26. The 1980 version of the Diagnostic and Statistical Manual of Mental Disorders (DSM-III) had solidified the idea that uncharacteristically persistent back pain could be a form of somatisation; see American Psychiatric Association, Diagnostic and Statistical Manual of Mental Disorders (Washington D.C., 1980), 241-244.

69 Kai Sievers and Hannele Palosuo, "Psykososiaaliset tekijät tuki- ja liikuntaelinten vaivoissa," in Kivun syyt ja säätely, eds. Kai Sievers, Veikko Laine and Raimo Raitasalo (Helsinki, 1982), 83-122, 100-101; see also Raimo Raitasalo and Kauko Nyman, "Psychosocial factors, Stress Symptoms and Absenteeism in Finnish Working Group," in Psychosocial Factors in Disease, eds. Kalle Achté and Antti Pakaslahti (Psychiatria Fennica Supplementum, 1979), 92-105, 94-95.

70 Greco, Illness as a Work of Thought, 30-31; see here also for a distinction of the differences between the concepts of 'psychosomatics' and 'somatisation'.

71 Veikko Kallio, "Toimintakyvyn rajoitukset ja taudin seurauksien selvittäminen," Sosiaalivakuutus, 25 (1987), 2-3; Harri Kruus, "Psykososiaalisten tekijöiden vaikutus työkyvyttömyyteen," Suomen Lääkärilehti, 39 (1984), 618-623; Tapio Melkas, "Selkävaivat ja työkyvyttömyys," Reuma, 29 (1981), 5 .

72 Veli-Matti Huittinen, "Mikä hoidossa auttaa," in Kivun syytja säätely, eds. Kai Sievers, Veikko Laine and Raimo Raitasalo (Helsinki, 1982), 185-189, 188.

73 Olli Korkala, "Milloin lumbaalinen diskusprolapsi olisi leikattava," Duodecim, 100 (1984), 738-740, 739 . 
behaviour. The development sparked a "psychosomatic rehabilitation research programme" at Kela, led by the neurologist Markku T. Hyyppä (b. 1942). ${ }^{74}$ In an article published in 1984, Hyyppä stated that psychosomatic symptoms (in which category he included chronic lower-back pain), had long remained the blind spot for rehabilitation. Hyyppä explicitly renounced the narrow psychosomatic concept of Franz Alexander and advocated the sociopsychological theory and stress research in rehabilitation. ${ }^{75}$ Together with the physiologist Erkki Kronholm, Hyyppä studied the psychophysiological and psychoendocrine changes connected to subjective symptoms. These symptoms were found to correspond to a perceived lack of agency, to a lack of the possibility to control one's environment, to poor sleep, and (particularly in the case of back pain) to masked depression. The authors' depression diagnoses, in the absence of overt psychopathology, were based on the dexamethasone suppression test, which was at the peak of its popularity during the 1970 on and the 1980 os. ${ }^{76}$ When these measurements actually omitted the patient experience altogether, the logic of the psychosomatic research programme suggested that bodily changes were more reliable witnesses of psychological strain than the patient's own testimony. ${ }^{77}$

Rehabilitation researchers formulated nuanced theories that aspired to understand the psychological and social-environmental context of back pain also outside the literal psychosomatic rehabilitation research. With the goal of treating patients rather than spines, back rehabilitation aspired towards a holistic approach. In particular, the comprehensive health ideal of the wHO and George Engel's biopsychosocial model found enthusiastic proponents at Kela, where researchers endorsed equally complex theoretical bases for rehabilitation. ${ }^{78}$ Kela and the Invalid Foundation (Invalidisäätiö) took a significant

74 Markku Hyyppä has long remained a central figure in Finnish psychosomatic research. Having studied, e.g., stress, sleep, psychoendocrinology, public health and rehabilitation practices, he is a docent in both neurology (University of Helsinki) and rehabilitative medicine (University of Turku). Furthermore, he has published a myriad of popular books on medical topics, including pain and psychosomatics.

75 Markku T. Hyyppä, "Psykosomaattinen oireilu - työkyvyn määrittämisen sokea täplä," Sosiaalivakuutus, 25 (1984), 259-263, 260. For a general discussion on the medical evaluation of pain disability, see, e.g., Stone, The Disabled State, 134-139.

${ }_{76}$ For a detailed analysis of the rise and decline of the test, see Edward Shorter and Max Fink, Endocrine Psychiatry: Solving the Riddle of Melancholia (Oxford, 2010).

77 Markku T. Hyyppä, "Uusia menetelmiä psykosomatiikan tutkimuksessa," Suomen Lääkärilehti, 39 (1984), 909-913.

78 George L. Engel, "The Need for a New Medical Model: A Challenge for Biomedicine," Science, 196 (1977), 129-136. The biopsychosocial and behavioural models occupied largely the same 
step towards a more comprehensive rehabilitation of back pain through the Intensive Physical and Psychosocial Training Programme (AKSELI) that started in the late 198 os. $^{79}$ The treatment and rehabilitation methods in AKSELI combined strenuous physical exercise with cognitive-behavioural stress management techniques. ${ }^{80}$ Through this approach, the distinction between organic and psychogenic pain became largely insignificant, in accordance with the explicit aim of the "biopsychosocial" or "comprehensive" rehabilitation model developed in the programme. Despite taking the biopsychosocial model as a starting point, the authors criticised Engel's 'new' medical model for differentiating the biological from the psychological and the social:

It seems to be difficult to understand the complementary nature of the physical, psychological, and social aspects of a disease, i.e. that patients' bio + psycho + socio condition must be exclusively examined in order to allow them to take advantage of their residual functioning. The biopsychosocial approach demands careful physical examination of the pain irrespective of any psychological disorders diagnosed in the patient. Similarly, patients waiting for disc surgery need the psychosocial aspects of their lives to be inspected too. ${ }^{81}$

This quote shows that the conclusions drawn about the nature of the back complaint had material underpinnings; the psychosocial claims were mirrored against corporeal findings and biological facts.

The examples and debates highlighted in this section make clear that the difficulties encountered by physicians when trying to bestow meaning on occurrences of back pain were grounded in the discrepancy between subjective experiences (as construed in the medical discussion) and objective views of the body in pain. As Kathleen Canning writes, historians have frequently analysed the body as a signifier of "nation or state power, of social formations or dissolutions, of moral or hygienic visions and dangers", and as a surface on which

problem area as psychosomatics; see, e.g., Raimo Puustinen, Is It Psychosomatic? An Inquiry into the Nature and Role of Medical Concepts (PhD thesis, Durham University, 2011), 171-179.

79 Veikko Kallio, Kuntoutuksen tiennäyttäjä: Kansaneläkelaitoksen kuntoutustutkimuskeskus 1972-1992 (Turku, 1995), 96-97, 100. The American orthopaedist Tom Mayer's active backrehabilitation techniques inspired the development of AKSELI.

8o Hannu Alaranta et al., "Intensive Physical and Psychosocial Training Program for Patients with Chronic Low Back Pain: A Controlled Clinical Trial," Spine, 19 (1994), 1339-1349.

81 Seija Talo et al., "The biopsychosocial disease consequence model in rehabilitation: model development in the Finnish 'Work hardening' programme for chronic pain," International Journal of Rehabilitation Research 19 (1996), 93-109, 97. 
morality, values and power are inscribed. ${ }^{82}$ To see the body this way seems justified in the light of the contemporary mind-body discussions, in which back pain could be regarded as a ruse to obtain disability pension or as a façade hiding an underlying strain or discontent. It is telling that a 1983 study from the Finnish Institute of Occupational Health stated that work absenteeism caused by back disease reflected "not only the levels of biological back disease, but also the state of and attitude towards social welfare, societal conventions, individual characteristics and especially worker's motivation and mental state".83

The development of the musculoskeletal pain discussion in the $1980 \mathrm{os}$ implies an increased interest in psychosomatic research. The first Finnish textbook on psychosomatics (1984) remarked that the "research on and the knowledge and practical applications of psychosomatics had strongly improved" at that time; ${ }^{84}$ similarly, the Google Books Ngram Viewer shows a peak in the use of the English word 'psychosomatics' and the German word 'Psychosomatik' around the 1980s. The attention, and with it the proliferation of concepts similar to psychosomatics, was arguably fostered by changing trends of illness that complicated the mind-body boundary work. Overall, the fact that psychosomatics and the related biopsychosocial model in rehabilitation no longer divided pain along Cartesian lines (to paraphrase David B. Morris's characterisation of postmodern pain $)^{85}$ did not appear to resolve to the mind-body problem. As the next section illustrates, the recognition should rather be seen as an agenda for the improvements that were still needed in pain management.

\section{Fibromyalgia, the Enigma of the Millennium}

In late twentieth century Finland, the appearance of baffling pain syndromes revived worries that people complaining of pain might be neurotics and shirkers. One syndrome that was particularly difficult to pin down was fibromyalgia, a conceptual successor of 'muscular rheumatism' or 'fibrositis', which had already been linked to psychological problems in post-war medical discussions. ${ }^{86}$

82 Kathleen Canning, "The Body as Method? Reflections on the Place of the Body in Gender History," Gender \& History, 11 (1999), 499-513, 500.

83 Tapio Videman et al., "Selkäsairaudet Saab-Valmetin Uudenkaupungin autotehtaalla vuosina 1976-1979," Sosiaalilääketieteellinen aikakauslehti, 22 (1983), 16o-170, 164.

84 Kalle Achté, Antti Pakaslahti and Ranan Rimón, eds., Psykosomatiikka: nykynäkemyksiä ja kliinisiä sovellutuksia (Helsinki, 1984), foreword.

85 David B. Morris, "Narrative, Ethics, and Pain: Thinking with Stories," Narrative, 9 (2001), $55^{-77}, 6$ o.

86 See footnote 34 . 
Referring literally to pain in the fibrous tissue, fibromyalgia was and is a diffuse syndrome characterised by widespread, chronic musculoskeletal pain and stiffness with comorbid fatigue and sleep problems. The improved diagnostic criteria from the American College of Rheumatology renewed medical interest in the condition in 1990. ${ }^{87}$ The contested diagnosis served a social purpose by reframing ambiguous ills as something that should entitle sufferers to treatment and compensation, and linked them to discussions around social insurance and rehabilitation. In Finland, the strong rheumatological tradition influenced the classification of pain and fatigue, making fibromyalgia a noteworthy diagnosis. ${ }^{88}$ This constitutes a clear difference to the Anglo-American situation, where the sister diagnoses of fibromyalgia, myalgic encephalomyelitis (ME) and chronic fatigue syndrome (CFS) respectively, viewed the fatigue symptom as paramount. ${ }^{89}$

This last section of the article examines the medical attitudes towards fibromyalgia diagnosis in the final decade of the twentieth century. It illustrates how the discrepancy between medical and lay opinions about the causes of fibromyalgia culminated in the questioning of medical expertise. It is argued that in the 199os, fibromyalgia was theorised, in part, as a psychosomatic manifestation of social and cultural change.

Whether the emphasis was on pain or fatigue, the 'new' syndromes were perceived as a means of withdrawal from a stressful society. In that, they were reflective of medical concerns about the pathogenic effects of stress. ${ }^{90} \mathrm{In}$

87 The rheumatologist Muhammad Yunus and his colleagues gave a well-known clinical description of fibromyalgia in 1981, when they identified increased tenderness at specific anatomical sites (tender or trigger points) as a typical sign of the condition; see Muhammad Yunus et al., "Primary Fibromyalgia (Fibrositis): Clinical Study of 5o Patients with Matched Normal Controls," Seminars in Arthritis and Rheumatism, 11 (1981), 151-171. It was refined in Frederick Wolfe et al., "The American College of Rheumatology 199o Criteria for the Classification of Fibromyalgia," Arthritis and Rheumatism, 33 (1990), 160-172.

88 Markku T. Hyyppä, Tunteet ja oireet: Uusin psykosomatiikka (Helsinki, 1997), 188.

89 See, e.g., Harry Collins and Trevor Pinch, Dr. Golem: How to Think about Medicine (Chicago, IL, 2005), 112-131; Shorter, From Paralysis to Fatigue, 307-314. The position of regarding fibromyalgia as a separate syndrome has become established in Finland, and there are outlines for effective treatment; see Nora Hagelberg, "Moniammatillinen kuntoutus fibromyalgian hoidossa," Duodecim Treatment Recommendations (1 December 2015), https:// www.kaypahoito.fi/nako8504, last accessed 25 April 2021. A similar recommendation for CFS was published only in 2021; see J. Komulainen et al., "Krooninen väsymysoireyhtymä (ME/CFs) Hyvä käytäntö -konsensussuositus," Duodecim Treatment Recommendations (23 February 2021), https://www.duodecimlehti.fi/duo16o87, last accessed 25 April 2021.

90 Cf. Marijke Gijswijt-Hofstra and Roy Porter, eds., Cultures of Neurasthenia: From Beard to the First World War (Amsterdam, 2014); Karin Johannisson, "Den moderna tröttheten: Från överansträngning till stress, kroniskt trötthetssyndrom och utbrändhet”, in 
Finland, the popular, medical and societal discussions established this connection. One sufferer, who appeared by the name Kirsti in the women's magazine Kotiliesi (roughly equivalent to 'Home and Heart'), shared a medical history familiar to many fibromyalgia patients. This secretary in her forties was burdened by unexplained aches and pains, and in the rheumatological practice, tender points in specific locations revealed fibromyalgia. Kirsti's tolerance for stress seemed to be permanently lowered, and she had to calm down her life in order to manage the symptoms. ${ }^{91}$ A physician from the FRA rehabilitation centre, Marja Hypén, described the typical fibromyalgia patient as an overly conscientious and unyielding woman, who continued to strain and exhaust herself even after the diagnosis. ${ }^{92}$ In the Finnish Parliament, the image of overexertion showed in a written question insisting that fibromyalgia sufferers were pilloried as hypochondriacs, mentally deranged or shirkers, when in fact most of them were just "middle-aged women under the double demands of working life and home". ${ }^{93}$ Juxtaposed with the stereotypical rheumatic of the 195os who 'just did not try hard enough', the ideal and threat of a hard-working, stressed individual became embodied in fibromyalgia.

From the very beginning, the medical discussion around the fibromyalgia diagnosis was riven with ambiguities. In 1991, reflecting the recognised public health significance of functional syndromes, the Mini-Finland Health Survey mapped the prevalence of fibromyalgia in the Finnish population. Its prevalence was estimated at a mere 0.75 per cent, but the study made a telling remark that altogether jettisoned fibromyalgia as a separate syndrome. It concluded:

Fibromyalgia resembles a constellation of stars: its components are real enough but the pattern is in the mind of the beholder. That ancient Greeks gave a group of stars the name of a mythical being is not reason

Långsiktig verksamhetsplan ur ett arbetsmiljöperspektiv: En handlingsplan för att förnya arbetsmiljöarbetet (Stockholm, 2001), 1-21.

91 Maarit Huovinen, "9o-luvun naisten lisääntyvä vitsaus fibromyalgia," Kotiliesi, 74 (1995), 9094, 93 .

92 Marjatta Nurminen, "Hyvä hoitosuhde auttaa fibromyalgiapotilasta," Reuma, 40 (1992), 4-5.

93 Ulla Anttila to the President of the Finnish Parliament, "Fibromyalgiaa sairastavien aseman parantamisesta," 30 December 1996, Document 971. On stress and double demands in Finland, see Mikko Myllykangas and Eve-Riina Hyrkäs, "Adaptation to the New Normal: Maternal Employment in the Framework of Psychosomatic and Stress Discourse in Finland from the 1950s to the Early 1970s," Social History of Medicine (2020), 12-16, doi: 10.1093/shm/ hkaao52. 
enough to suppose that the constellation has any actual meaning, much less the attributes of the creature. ${ }^{94}$

The quoted remark hints at why the initially perceived benefits of outlining fibromyalgia as a non-malignant syndrome - relieving patient anxiety and reducing the use of healthcare services - were soon seen as detrimental. According to the rheumatologist Frederick Wolfe, the first author of the 1990 fibromyalgia criteria, a distinct diagnosis seemed to create an illness instead of assuaging patients' feelings of infirmity. ${ }^{95}$

The lack of objective findings and fibromyalgia's connection with psychiatric illness generated a seemingly endless stream of new explanatory theories. A 1996 international review suggested that the seat of fibromyalgia should be sought from, for example, muscle energy metabolism, disordered sleep, serotonin, regional blood flow in the brain, hypothalamic-pituitary-adrenal axis function and depression. ${ }^{96}$ Particularly, the psychogenic hypotheses of fibromyalgia perplexed and intrigued physicians. ${ }^{97}$ For instance, the Finnish psychiatrists Jouko K. Salminen and Simo Saarijärvi (having studied, respectively, alexithymia and back pain at Kela) suggested that fibromyalgia patients' apparent inability to see a connection between their ailments and psychological states could be caused by alexithymia. ${ }^{98}$

Diagnostic uncertainties led to fibromyalgia sufferers falling through the net of compensation entitlements. The issues were largely unchanged from those raised in the backache debate. What differed was the extent to which sufferers were willing to stand up to make their demands known. At first, the FRA took fibromyalgia sufferers under its wing, and in 2019, the patient advocacy culminated when the Finnish Fibromyalgia Association was established to "dismantle persistent prejudices" and to "make fibromyalgia a legitimate cause for sick leave and disability pension". ${ }^{99}$ That the fibromyalgia patients took an active

94 Matti Mäkelä and Markku Heliövaara, "Prevalence of Primary Fibromyalgia in the Finnish Population," British Medical Journal, 299 (1991), 216-219, 218.

95 Collins and Pinch, Dr. Golem, 120.

96 Robert Simms, "Fibromyalgia Syndrome: Current Concepts in Pathophysiology, Clinical Features, and Management," Arthritis Care and Research, 9 (1996), 315-328, 315-317.

97 See, e.g., Pirkko Rahinantti, Psyykkiset tekijät fibromyalgiassa (Kuopio, 1998); Pekka Hannonen, "...kun epäillään fibromyalgiaa?" Suomen Lääkärilehti, 51 (1996), 1201; Marjatta Peltoniemi, "Fibromyalgia - romukoppasairaus," Reuma, 36 (1988), 16-17.

98 Jouko Salminen and Simo Saarijärvi, "Fibromyalgia psykiatrian näkökulmasta," Suomen Lääkärilehti, 50 (1995), 2925.

99 Fibromyalgiayhdistys (website), “Tietoa yhdistyksestä”, www.fibromyalgiayhdistys.com/ tietoa-meista, last accessed 25 April 2021. 
stance in both the diagnosis and compensation issues illustrates the shifting balance between medical knowledge and lay perceptions of health. ${ }^{100}$ The debate about fibromyalgia and amalgam dental fillings taken up in the opinion columns of Reuma in the early 199os provides a telling example. Then, a sufferer informed other readers that taking a sauna bath could vaporise mercury from teeth fillings, which made fibromyalgia symptoms worse the following day. ${ }^{101}$ The opinion was commented on by Risto Isomeri, the then head physician of $\mathrm{RFH}$, who reminded readers that "the relationship between fibromyalgia and amalgam was still open [to question]", as was the very existence of an "amalgam disease".102 The reader responses were quick to demand that if patients felt that their illness was alleviated through the removal of amalgam fillings, then medical experts should try to prove the usefulness of such a measure experimentally. One reader, who had a master's degree in metallurgy, went so far as to offer Isomeri an education on the increased mercury load of the average person that "might even be the root cause" behind the proliferation of functional complaints in the recent decades. ${ }^{103}$

Building on the previous example, the medical discussion around the fibromyalgia diagnosis brought up the question of patient agency. Although familiar notions of somatisation and malingering prevailed, historical analysis of fibromyalgia discussion unveils a layer of agency that cannot be reduced to these concepts; fibromyalgia sufferers deviated from the expected patient behaviours. Following the sociologist David Armstrong, in the late twentieth century, we could say that patients adopted expert positions in respect of their own health. ${ }^{104}$ This was especially true for fibromyalgia patients. The medical profession met this patient proactivity with considerable unease, which can be observed not only in the Finnish sources, but also in certain historical accounts of fibromyalgia. ${ }^{105}$

A particular point of contention was that patients with fibromyalgia rejected the psychogenic explanation, and in that, participated in the mindbody boundary work. Their motivation for doing so is spelled out in the pages

\footnotetext{
100 See, e.g., Shorter, From Paralysis to Fatigue, 295, 317; Collins and Pinch, Dr. Golem, 114-115, 122-125.

101 Liisi Suikkala, "Amalgaamin poisto helpotti oloa," Reuma, 41 (1993), 7.

102 Risto Isomeri, "Amalgaami ja fibromyalgia", Reuma, 41 (1993), 7

103 Heikki Peltola, "Amalgaamissa elohopeaa aikaisempaa enemmän," Reuma, 42 (1994), 7.

104 David Armstrong, "Actors, Patients and Agency: A Recent History," Sociology of Health \& Illness, 36 (2014), 163-174, 169-170.

105 See Shorter, From Paralysis to Fatigue, 311-314; Edward Shorter, "Sucker-Punched Again! Physicians Meet the Disease-of-the-Month Syndrome," Journal of Psychosomatic Research, 30 (1995), 115-118.
} 
of a collection entitled Minun fibromyalgiani ('My Fibromyalgia'), in which twenty-three patients described in a heartfelt manner how their illness was not understood, how they were viewed as shirkers, and how they were referred to with a dismissive term 'hurt-all-over' (joka paikan kipeä). ${ }^{106}$ Hence, identifying an organic cause appears to have been a means to acquire moral validation about feeling ill. As Simon Wessely argues, highlighting some neurological, immunological or noxious cause tends to minimise patients' own complicity in ambiguous syndromes. ${ }^{107}$

On the practical level, fibromyalgia's doubtful claim to corporeality had far-reaching consequences. The illness constituted a significant cause of absenteeism from work and overuse of healthcare services, but sufferers' right to receive disability benefits was constantly under review. In 2000, Lauri Keso, the expert physician at the Finnish Local Government Pensions Institute, posited the inflammation caused by rheumatoid arthritis as a yardstick for objective medical grounds for pension eligibility; the absence of such physical proofs in fibromyalgia would render many sufferers ineligible, but Keso continued to point out how severe comorbid depression legitimated some sufferers' pension claims. ${ }^{108}$ The problem of fibromyalgia, then, was not the lack of anatomic findings per se, but that the diagnosis was an anomaly in the context of compensation claims procedures. Since fibromyalgia was discussed as an organic disease with an unknown cause, the burden of somatic proof became heavier than it was in cases of psychiatric illness. This ambiguity around the causes of fibromyalgia trapped many of the sufferers into a vicious cycle of disability indetermination. A contribution to Kela's fibromyalgia rehabilitation seminar, organised in 1999, emphasised that if patients were met with insults or doubt in relation to the nature of their pain, finding a somatic diagnosis easily became a question of dignity. The initial motive of the patient - the keeping intact of their own personal dignity - could turn into a passive way of life, overshadowed by disputes over rights to unemployment benefits or pensions. ${ }^{109}$ That one of the criteria for fibromyalgia diagnosis in Finland was a reduction of the patient's working capacity by at least fifty per cent made plain the vicious cycle of pain disability. ${ }^{110}$

\footnotetext{
106 Finnish Rheumatism Association, Minun fibromyalgiani (Helsinki, 1997).

107 Simon Wessely, "Old Wine in New Bottles: Neurasthenia and 'ME', Psychological Medicine, 20 (1990), 35-53, 45 .

108 Marja-Liisa Takala, “Fibromyalgia - sairautta vai oireilua?” Työeläke, 36 (2000), 18-20.

109 Jukka-Pekka Kouri, "Pitääkö kroonista kipua hoitaa ja/tai/vai kuntouttaa kroonisesta kivusta kärsivää ihmistä," in Fibromyalgia ja kuntoutumisprosessi: Enigma 20oo? ed. Seija Talo (Turku, 1999), 109-122, 117.

11 Markku T. Hyyppä et al., Kipu-uupumusoireiden pysyryys ja kurssimuotoinen fibromyalgiakuntoutus (Turku, 1998), 11.
} 
In the fibromyalgia discussion, psychogenic illness explanations were tightly entwined with the state of the Finnish society. When Hyyppä reviewed the issue in the journal Sosiaalivakuutus ('Social Insurance') in 1998, he described the role of financial compensation in arguments about fibromyalgia's resistance to rehabilitation as "downright embarrassing". In Finland and other countries with good social welfare, he complained, patients seemed to view rehabilitation only as a stepping-stone towards disability pension. ${ }^{111}$ That the fibromyalgia issue emerged in the first place was also attributed to social change, which had allegedly lowered the general threshold for pain. One of the first descriptions of fibromyalgia, published in 1989 in Suomen Lääkärilehti ('Finnish Medical Journal'), had already connected the illness to the hypothesis that "better living standards had led people to expect a painless life". ${ }^{112}$ The anaesthesiologist Wilfried Witte has attested that something similar was seen in the post-war West Germany, where psychosomatic theories seemed to support culturally pessimistic views that modern people needed to be "anaesthetised" because they could no longer bear suffering. ${ }^{113}$ Further, in the Anglo-American context, the historian Edward Shorter has argued that, since the late twentieth century, people have developed an increased hypervigilance towards their bodily functions. ${ }^{114}$ The familiar themes of being indolent and hypersensitive invoked in the rheumatoid arthritis and backache discussions acquired a different complexion in the 1990s. They were now regarded more as a product of social persuasion than a misfortune in personality development.

That fibromyalgia was debated in the psychosomatic framework demonstrates that physicians deemed the social world powerful enough not only to intensify symptoms, but also to create and sustain distinct diagnostic categories. This connection narrowed the boundary between treatments and judgments in the discussions on fibromyalgia, and prompted patients to engage in the mind-body negotiation. The example of fibromyalgia shows the continued relevance of the mind-body problem in pain. Even as cutting-edge brain imaging techniques promise to enhance the treatment of pain and the credibility of

111 Markku T. Hyyppä, "Fibromyalgiakuntoutuksen vaikuttavuudesta," Sosiaalivakuutus, 36 (1998), 15-17. Lääkärilehti, 44 (1989), 3286-329o, 3286.

113 Wilfried Witte, "The Emergence of Chronic Pain: Phantom Limbs, Subjective Experience and Pain Management in Post-War West Germany," in Pain and Emotion in Modern History, ed. Rob Boddice (Basingstoke, 2014), 90-110, 102-105. 
patient experience, the significance of the mind-body problem is unlikely to diminish anytime soon. ${ }^{115}$

\section{$5 \quad$ Conclusion}

In the Finnish medical discussion of musculoskeletal pain in the latter half of the twentieth century, the personal characteristics of patients and social hypotheses became entangled with medical statements. The interests and values invoked at different times formed part of the same construct, although the focal points of the pain debate varied. The story that emerges is not tantamount to the triumph of 'psychosomatic pain' in the history of pain management, but testifies to the continued relevance of the mind-body problem that was voiced through different concepts (most notably, psychosomatics, stress and the biopsychosocial model) and within numerous disciplines. These discussions and the variety of actors who engaged in them addressed a determination to dissolve the partly artificial boundaries between society, the mind and the body. While this article has discussed pain disability in different theoretical and historical frameworks, I concur with the historian Keith Wailoo's general observation with regards to the discussion of pain in the US, when he contended that medical theories seem to have "followed (rather than led) society's cultural arguments."116

The history of mind-body boundary work helps us to understand the continued resistance of some patients to the psychologisation of their illness. As the American anthropologist Jean Jackson suggests, the tendency to stigmatise chronic pain stems from the 'liminal status' of sufferers that does not fit neatly into distinct Cartesian categories. ${ }^{117}$ In Finland, the medical use of the term 'psychosomatic' often questioned patients' narratives regarding their symptoms. The term delineated a difference between the perceptions of the patient and those of the physician, at least to the extent that patients' attitudes can be deduced from published reader comments. This gap was soon filled with suspicion as to the motives behind patients' seeking medical help for such symptoms or the imposition of a psychogenic theory. The historical research on various compensation neuroses has long argued that medical authorities

115 See, e.g., Markku Mali, "Eväitä fibromyalgian kohtaamiseen," Suomen lääkärilehti, 71 (2016), 1371-1375.

116 Wailoo, Pain, 207.

117 Jean Jackson, "Stigma, liminality, and chronic pain: Mind-body borderlands," American Ethnologist, 32 (2005), 332-353. 
tend to deem patients without lesions as neurotics or liars. ${ }^{118}$ However, finding an organic lesion did not necessarily remove these kinds of suspicions, and the determination of disability and rehabilitation often required psychosomatic boundary work beyond the alleged psychogenic cases. The case studies in this article underline that the mind-body problem was not just a philosophical curiosity, but also a recurring point of negotiation that had very real implications for the lives of pain sufferers.

The above findings open up interesting possibilities for the historiography of pain and medicine. The discrepancy between the objective and subjective views of bodily functions is informative, since weighing the organic and psychogenic factors in disease compels physicians to step outside the confines of biomedical rationale. The lack of organic findings (or inadequacy thereof) requires a more explicit elaboration as to why the patient feels ill. The hypotheses conjured up in these situations derive from the historical context in which the evaluation takes place. Hence, descriptions of the 'mind' behind the 'body' uncover the values, moral norms and social expectations that underlie biomedicine, and make them conspicuous to historians. In the history of psychosomatics, bodies may speak, but physicians determine the meanings of these embodied statements.

\section{Acknowledgements}

The author thanks Petteri Pietikäinen, Heini Hakosalo and Mikko Myllykangas for their comments and support. Thanks go also to the anonymous reviewers for all their help.

118 See, e.g., Eric Caplan, "Trains, Brains, and Sprains: Railway Spine and the Origins of Psychoneuroses," Bulletin of the History of Medicine, 69 (1995), 387-419; Ralph Harrington, "On the Tracks of Trauma: Railway Spine Reconsidered," Social History of Medicine, 16 (2003), 209-223; Ryan Ross, "Between Shell Shock and PTSD? 'Accident Neurosis' and Its Sequelae in Post-War Britain," Social History of Medicine, $3^{2}$ (2019), 565-585. 